\title{
PSYCHE.
}

\section{THE PRIMITIVE NUMBER OF MALPIGHIAN VESSELS IN INSECTS.-VII.}

\author{
BY William MORTON WheEler, PH.D., CHicAgo, ILl.
}

With these conclusions the object of the present paper is attained. As stated in the beginning, the homologies of the Malpighian vessels with other insect or vermian organs are most obscure, and if I venture to add some remarks of a critical nature, it is in the belief that a discussion of the difficulties attending the establishment of such homologies is not without a certain, albeit negative value.

It is an interesting fact, which has impressed several observers, that the fore-gut, and more especially the hindgut in many insects, have a very regular hexagonal outline. This is most readily seen in the more primitive orders, like the Orthoptera, where it extends even to the mid-gut which is of entodermal origin. Minot* was struck with this peculiarity while studying Melanoplus. "I cannot but think," he concludes, "that it (the curious repetition of the number six) will be ultimately found to have some hitherto unsuspected meaning. There are six rows of teeth in the proventriculus, six diverticula arising from the stomach, and twelve longitudinal

\footnotetext{
* Histology of the locust (Caloptenus) and the cricket (Anabrus). Second rep. U. S. ent. comm. 1878-79 relat. ing to the Rocky Mt. locust. 1880. pp. 220-221.
}

folds in each diverticulum. There are twelve (twice six) gastroileal folds, arranged in twos, each pair appearing as the double anterior termination of the six ileal folds, which, changing their character, extend backwards through the colon; finally in the rectum there are six rectal glands."

The hexagonal symmetry of the hindgut makes its appearance during embryonic life, as I have observed in members of the orders Orthoptera, Coleoptera and Lepidoptera. The Malpighian vessels arise at the 6 angles, or horns of the proctodaeal wall. There is evidently, therefore, some correlation between the 6 vessels and the hexagonal outline of the hind-gut.

Miall and Denny* were, I believe, the first to offer an explanation for the hexagonal structure of the rectum. They are of the opinion that "the tendency to produce a 6 -banded stomodaeum and proctodaeum may possibly be related to the 6 theoretical elements (two tergal, two pleural, two sternal) traceable in the Arthropod exo-skeleton, of which the stomodaeum and proctodaeum are reflected folds."

\footnotetext{
*1. c. p. 126 .
} 
Mingazzini * too in his study of the alimentary canal of the phytophagous Lamellicornia . concludes that the hexagonal structure of the rectum is "di grande importanza filogenetico, perchè si riscontra in quasi tutti gli ordini d'insetti finora studiati." Mingazzina adds as further evidence to Miall and Denny's suggestion that the proctodaeum presents 6 bands of longit udinal muscles corresponding to the 6 longitudinal muscles of a segment.

Miall and Denny's hypothesis is certainly ingenious, but $I$ fear that it is untenable. To be admissible it would require that each of the 6 sides of the hind-gut should be parallel to one of the 6 exoskeletal elements of the segment (Fig. I). The median dorsoventral

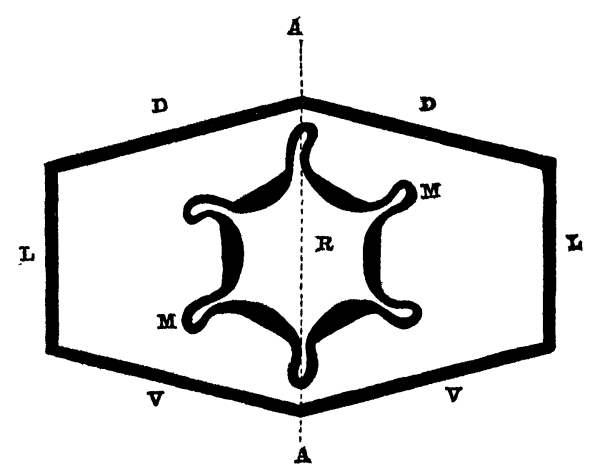

FIG. I.

plane, represented by the line $\mathrm{A} A$, should cut the prismatic hind-gut into two symmetrical halves, either of which

\footnotetext{
* Ricerche sul canale digerente delle larve dei lamellicorni fitofagi. Mitth. zool. stat. Neapel. bd. ix heft i, 1889, p. 95 at seq.
}

would contain three entire planes. But in reality this is not the case, as sections through the embryo show (Fig. 2.); there being in the proctodaeum one dorsal, one ventral, and on either side two pleural planes. The median dorsoventral plane A A cuts the procto. daeum into two symmetrical halves,

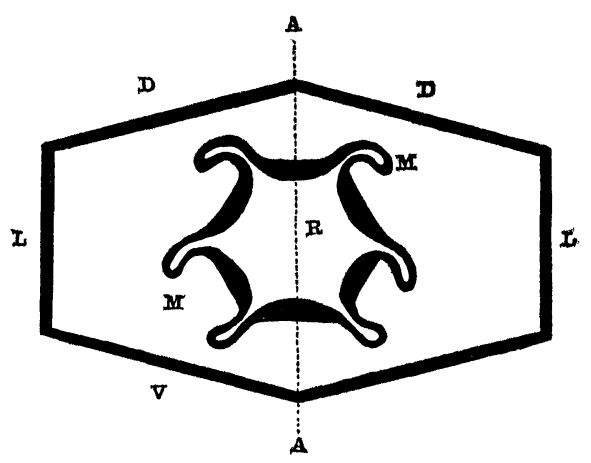

FIG. 2 .

either of which consists of two entire and two half sides. It is therefore necessary to suppose either that the rectum has undergone a rotation of $30^{\circ}$ on its median longitudinal axis - and this would produce a torsion of which there is not the slightest evidence in the embryo or adult-or that a single side of the proctodaeum does not correspond to a segmental element and this is, of course, equivalent to abandoning the hypothesis altogether.*

* Miall and Denny's remarks are hardly explicit enough. I have interpreted their hypothesis as refering to the sides and not to the angles of the hind-gut. On the supposition that each corner, or horn with the adja. cent half sides is regarded as equivalent to an exoskele. tal element, no very serious objection can be raised to the view. 
The actual position of the proctodaeum in the body of the insect leaves no doubt that the Malpighian vessels are paired structures; there being a dorsal, a pleural and a ventral pair. These may be readily resolved into an anterior, median and posterior pair, if we go back to the earliest stage in the formation of the hind-gut and its diverticula in such a form as Doryphora. At this time the future long axis of the proctodaeum lies at right angles to the long axis of the ventral plate, so that the vessels budding from its walls may be regarded as arising in three consecutive pairs.

If we go a step further and look for the meaning of the paired arrangement of the vessels we are at once confronted with difficulties. Two alternatives present themselves :

I. The number of vessels is simply correlated with the number of rectal folds, and the regular prismatic character of the rectum requires some other explanation than the presence of the vessels, since it recurs also in the foregut. According to this alternative the 6 Malpighian vessels belong to one segment, the eleventh abdominal, or telson, from which the proctodaeum arises.

2. Each pair of vessels represents a metameric unit. Hence three separate segments must have contributed to the formation of the proctodaeum. This alternative, if accepted, only leads to further difficulties, since the vessels must either be the serial homologues of paired ectodermal structures be- longing to the more typical anterior abdominal segments or such structures no longer exist in the Insecta and must be sought for in the more ancestral Articulata (Annelida presumably). Insect structures which may be homodynamous with Malpighian vessels are:-

$a$. The tracheae. These are known to arise as tubular invaginations of the integumental ectoderm pleurad to the appendages, a pair to a segment. They occur only as far back as the eighth abdominal metamere. As the ninth, tenth and eleventh segments are etracheate we might hope to fill this gap with the three pairs of Malpighian vessels, on the assumption that these diverticula had in some way come to arise from the proctodaeal instead of the integumental ectoderm.

b. The oenocyte-clusters. These, as I have shown in a former paper, ${ }^{*}$ arise as paired ectodermal cell-masses just caudad to the tracheae. They, too, are wanting in the ninth to eleventh segments.

The Malpighian vessels resemble the tracheae in being tubular, the oenocytes in the glandular character and large size of the cells. The faint invagination, which still accompanies the formation of an oenocyte-cluster in embryonic Orthoptera and Coleoptera, may be the last trace of the lumen of a tube, the disintegrated walls of which are now represented by the oenocytes.

$c$. The nephridia. I have pointed

* Concerning the "blood-tissue" of the Insecta. Psy. che. Feb.-April, 1892. 
out* that the sexual ducts arise in Xiphidium as hollow diverticula of the somites, like the nephridia and sexual ducts of Peripatus. It is, however, only the mesodermal portion of the nephridia which arises in this way; if what students of annelid development tell us prove to be correct, each nephridium must also have a small proximal piece derived from the ectoderm. The oenocyte cluster may be this piece disintegrated and changed in function. I deem it probable that the insect nephridium has passed through the following stages:

I. The nephropore (now represented by the oenocyte pit in the embryo) became occluded and then obliterated together with the lumen of the ectodermal portion of the nephridium.

2. With further degeneration the ectodermal and mesodermal anlagen of the nephridium failed to unite during ontogeny and persisted as separate structures.

3. These two anlagen took on new functions - the ectodermal or oenocyte portion acquiring some function perhaps analogous to that of the thymus in vertebrates; the mesodermal portion becoming converted partly into the corpora adiposa and in part into the sexual ducts. $\dagger$

* A contribution to insect embryology. Journ. of morph. vol. viii, no. I. 1893, p. I 6 et seq.

$\dagger$ The fat-body retains to this day a nephric function inasmuch as it stores up urates often in considerable quantity. Kowalevsky (Ein beitrag zur kenntnis der
The Malpighian ressels, if at all comparable to nephridia, can represent only the ectodermal (oenocytic) ends. On the trisegmental hypothesis the vessels would be equivalent to three pairs of oenocyte-clusters, which had preserved their tubular character and excretory function. But the great difficulty lies in understanding the process whereby these three pairs of metameric and originally integumental structures could be carried into the anal invagination and appear ontogenetically as hollow buds at its inner end. On the other hand my hypothesis is beset with fewer difficulties, if we suppose that the three pairs of Malpighian vessels do not represent three metameres, but only a single one, for it is easy to understand how a single pair of oenocyte tubules could be carried in and subsequently, in the remote ancestors of existing insects, give rise to three pairs of vessels by a simple process of budding.

These considerations lead me to reject the trisegmental hypothesis and, while regarding 6 as the primitive number of Malpighian vessels in insects, to postulate only a single pair in more ancestral Articulata.

The University of Chicago.

Sept. I892.

exkretionsorgane. Biol. centralbl. bd. ix, 189o, p. 42 et seq.) in a long series of experiments found that carmine, chloride of iron, and litmus were abstracted from the blood by the cells of the pericardial fat.body. In Muscid larvae the cells of the garland-shaped strand have a similar function. 

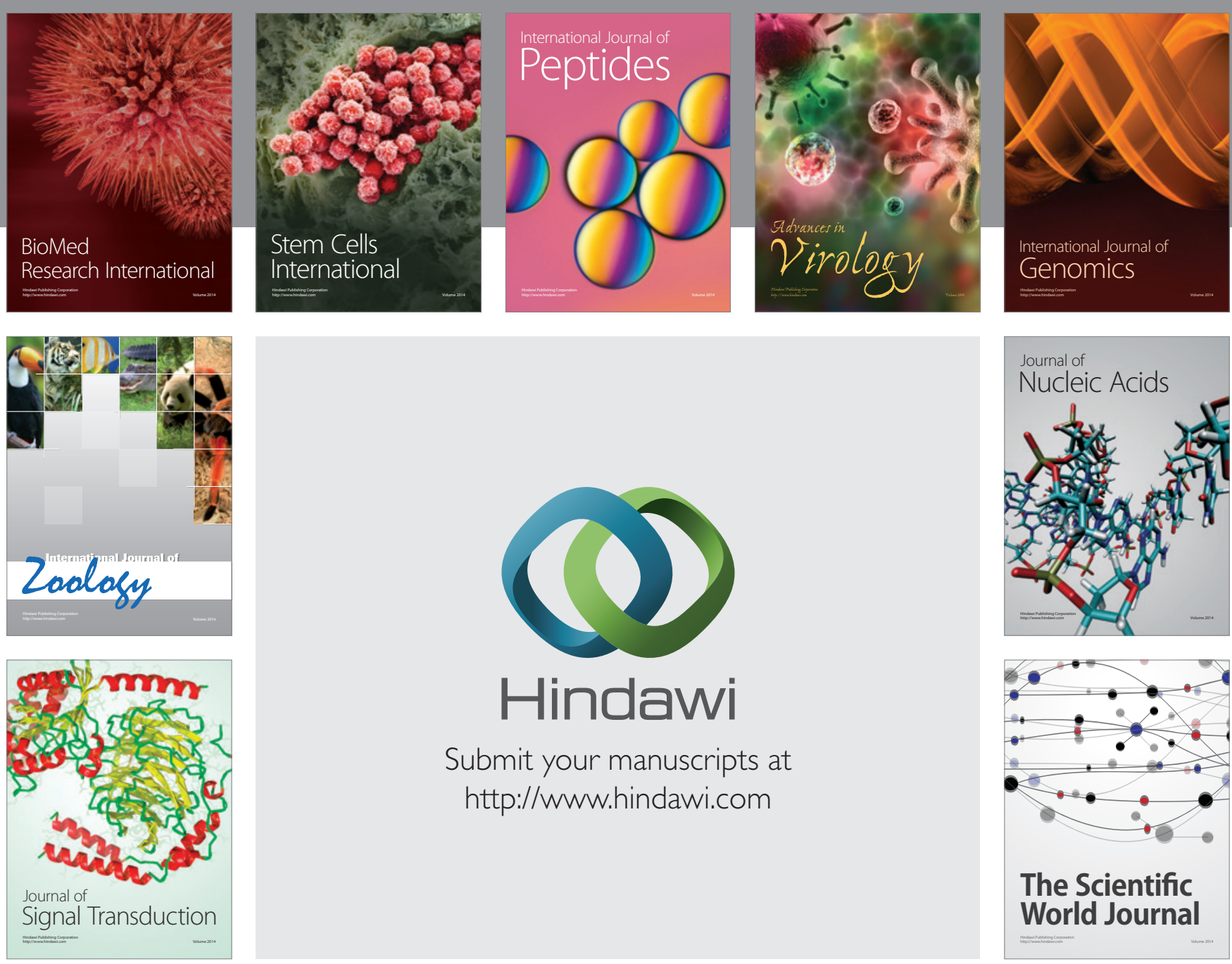

Submit your manuscripts at

http://www.hindawi.com
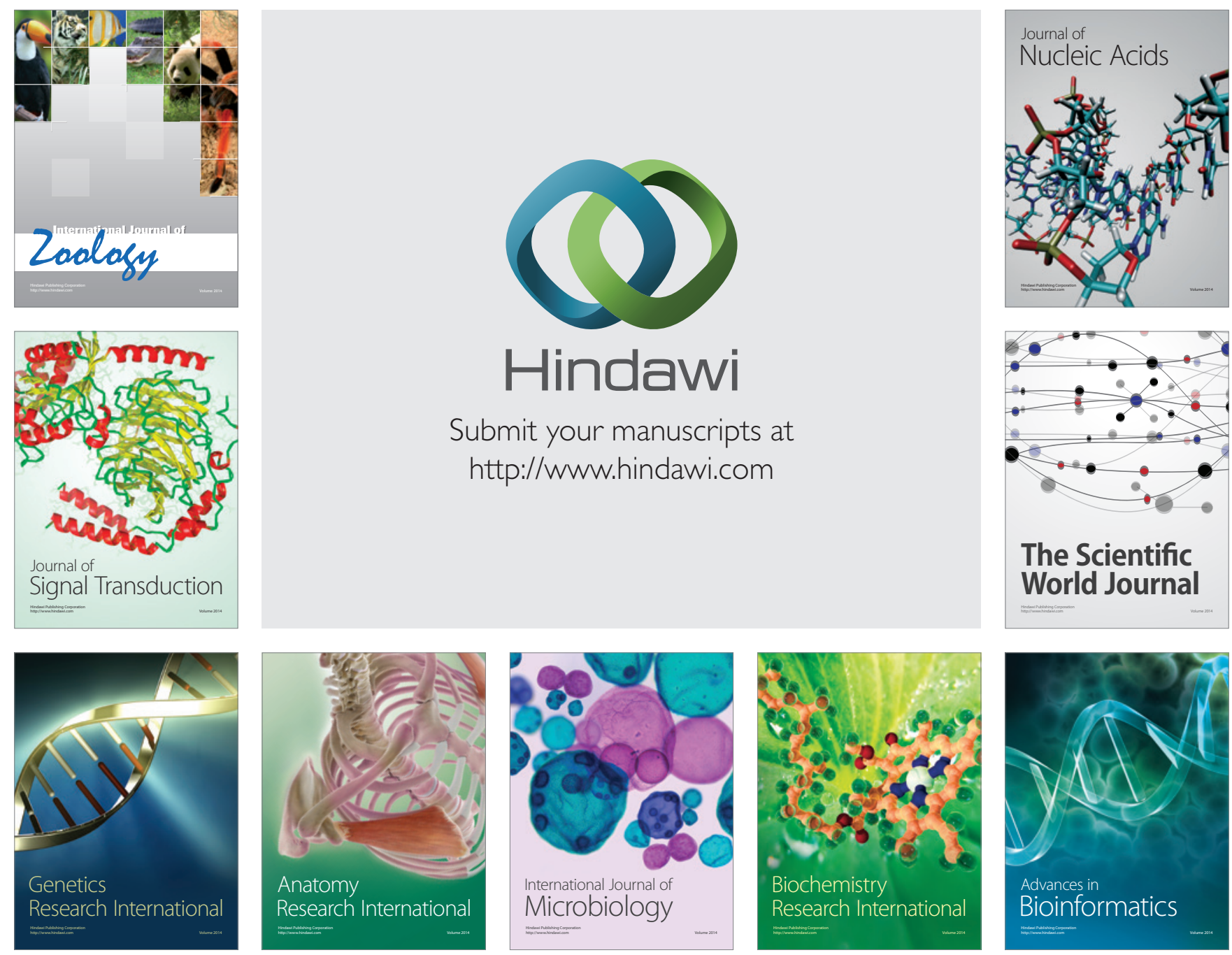

The Scientific World Journal
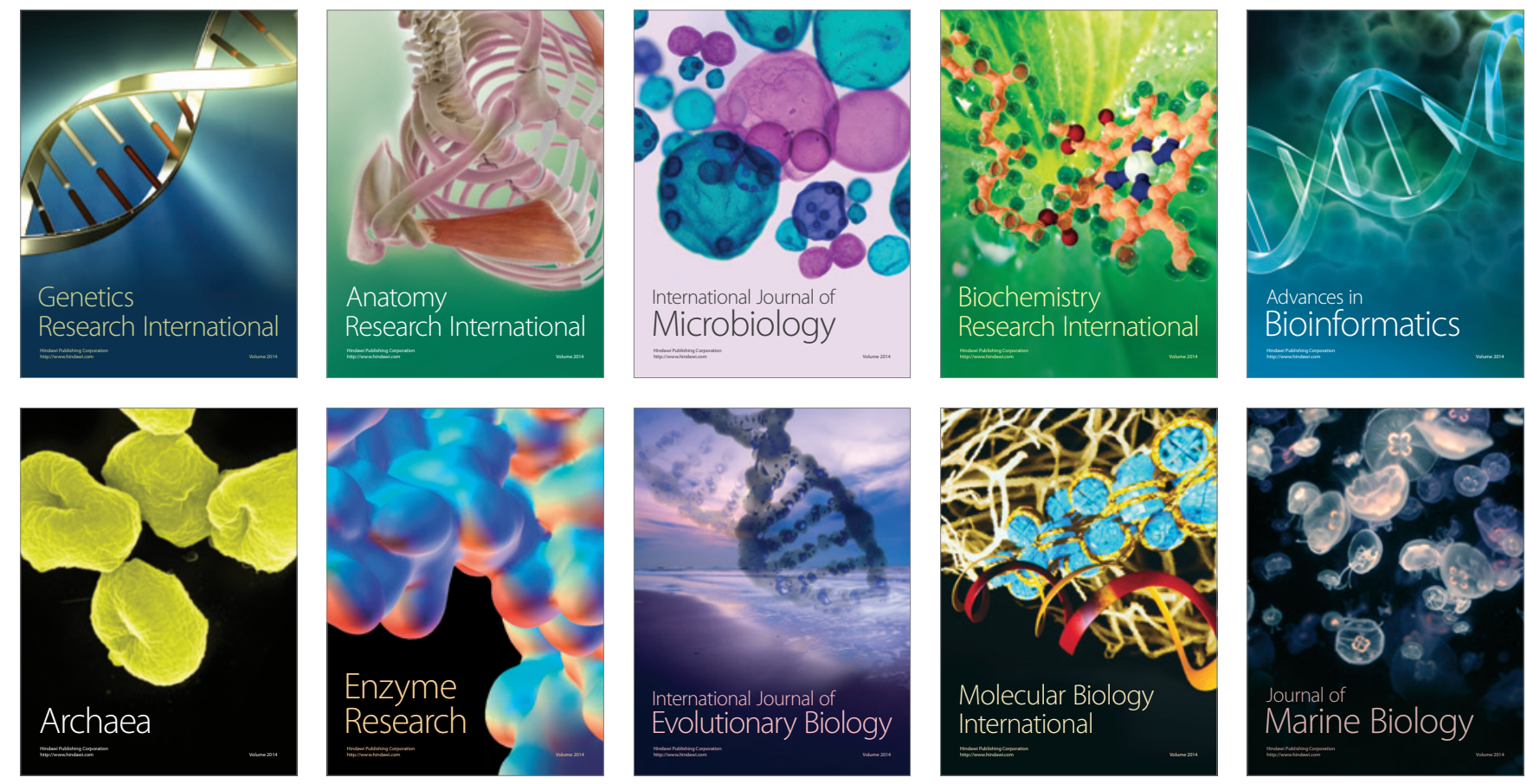